\title{
Party political chaplaincy? - Methodist ministry to political parties
}

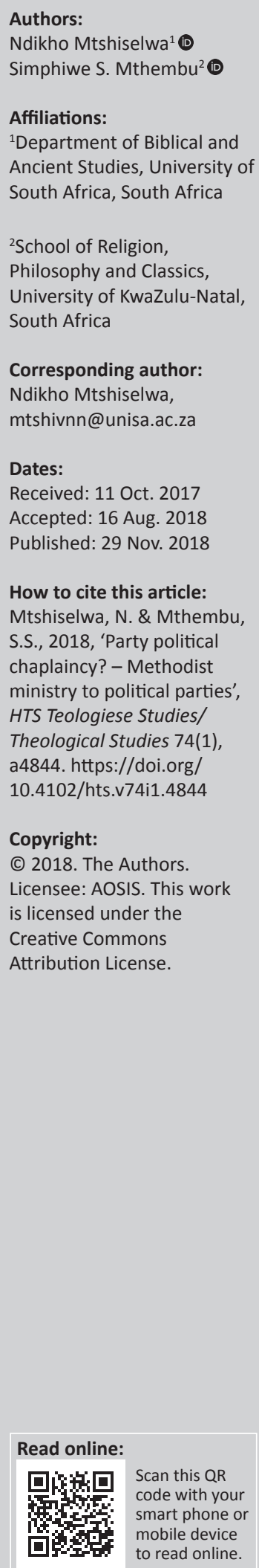

The debate on church and party politics is far from being exhausted in South Africa. Although the Methodist Church of Southern Africa discourages the participation of clergy persons in political parties, it is becoming critical that the church offers a prophetic voice in the political sphere. Issues of morality and spirituality within the political parties necessitate a careful involvement of the Church in politics. This article therefore sets out to offer a theological reflection on the (possible) ministry of Methodist clergy persons to political parties in South Africa.

\section{Introduction}

The issue of the participation of clergy in party politics necessitates that we have a theological reflection on 'party political chaplaincy' in the Methodist Church of Southern Africa (MCSA). The reflection in this article is mainly based on the 2016 conference resolution (MCSA 2014, par 2.27 Party political chaplaincy):

Conference 2016 affirms the 2014 and 2015 resolutions not to appoint ministers as chaplains to political parties. Conference further affirms our stated position on the religion and politics along with the conviction that our ministry extends to all spheres including social, economic, political and environmental spheres of life. Conference directs DEWCOM to develop a guiding theological document and practical tools that will shape our response, describing amongst other things:

- the pastoral and prophetic nature of our ministry in the political and public space;

- possible expressions/forms of our ministry in the public/political domain including nonpartisan ministry to political parties, governments, national parliaments, provincial, regional and municipal institutions and traditional spheres of leadership. (p. 223)

Based on this resolution, this article sets out to offer a theological reflection and guidelines that may shape the discernment and position of the MCSA on the issue of 'party political chaplaincy'. Worthy of note in the debate of church and party politics is a compelling argument made by Tshaka and Senokoane (2016) that:

Politics is unavoidable. The likes of Luther, Calvin, Barth and others have indicated on several occasions their inclination to be biased towards democracy. Decisions about the economy, society and beliefs are taken in the political realm. Thus, the absence of a Christian in politics implies that a Christian is not part of this decision-making process and, because what affects the individual in the Christian community also affects the same individual in the civil community, the idea of the Christian from politics is in fact absurd. (p. 1)

Said differently and most importantly from a Methodist theological perspective, the ministry of Christians extends to the political sphere (MCSA 2014:223). It may thus be decisively argued that the incarnate Christ is at work in the political sphere through the presence and ministry of the Church, which in essence is the 'Body of Christ'. However, the possible ministry of the Church in the political and public space is rather complex because the members of the MCSA affiliate to different political parties and because of the point that the closer relations between the church and political parties could compromise the independence of the Church in its witness to the Gospel. It is thus critical that we discern the pastoral and prophetic nature of the ministry of the MCSA in the political space.

\section{History of the Methodist Church of Southern Africa in the political sphere}

The literature on the history of the Church in Southern Africa reveals that the MCSA has directly and indirectly been involved in politics. A cardinal question to ask is as follows: what has been the 
historic pastoral and prophetic nature of the ministry of the Church, especially the MCSA, in the political and public space? In its nature, the idea of politics is about the governance of people. The church believes that God's people should be governed well, with truth, justice and peace as well as with common good. In cases where politics did not provide truth, justice and peace to God's people, the Church historically raised her concerns. Prior to the 1994 democratic elections in South Africa, for instance, the Church was concerned with the apartheid system that was oppressive to the majority of the South African people. An account of how the church fought against the system that was evil to humankind is well documented (De Gruchy1986). In the epoch of apartheid, the MCSA took her political stand as early as 1948 (De Gruchy1986):

The Methodist Conference that same month (in 1948) stated that no person of any race should be deprived of constitutional rights or privileges merely on the grounds of race, morally binding contracts protecting such rights should be regarded on the high level of a pledges word. (p. 54)

This commitment became compelling during the struggle against a system that was oppressive to many South Africans as it called for a society where all the citizens of the country had dignity. The theology that all human beings are equally made in the Image of God informed the commitment to criticise the governing political party that entrenched inequality and injustice. The church rejected racism and came with a statement that it is God's will to be a 'one and undivided' church.

In 1958, the conference of the MCSA declared its conviction that the Methodist Church should be 'one and undivided' in opposition to the apartheid state's intentions to segregate the nation and the Church (MCSA 1958:65). This conviction expressed a clear intent to keep people of different races, ethnic groups and cultural backgrounds united within the MCSA. In an attempt to re-affirm the conviction of 1985, the MCSA held a conference in 1981 that later came to be known as Obedience '81. The conference made a declaration of its conviction that it is the will of God for the Methodist Church that it should be 'one and undivided' (MCSA 1982). The Obedience ' 81 decision came at the height of the oppressive and violent enactment of apartheid in South Africa. Subsequent to Obedience '81 was Journey to New Land, which shaped the Church's identity between 1992 and 1995. This was a clear response to the winds of change which were engulfing the South African political landscape at that time. A case in point here is that the MCSA recognised that it had a responsibility to participate in the social and political changes of that period. It may thus be deduced that the MCSA has historically offered a positive contribution in the political sphere of Southern Africa.

Furthermore, the MCSA offered a positive contribution in the struggle against apartheid as a member of the South African Council of Church (SACC). Worthy of note is the point that the SACC issued a historic statement 'Message to the People of South Africa' that rejected apartheid as a 'pseudo-gospel' and called Christians to obey God rather than man (VillaVicencio1986:200). The statement was made during a period where some churches in South Africa supported the system of apartheid. A closer look at such a period shows that the solidarity of some churches with the governing political party compromised the independence of the Church in its witness to the Gospel. Segregation of the people was in contrast to the will of a triune God who wishes human beings to live in harmony and peace with each other.

Furthermore, the direct link of the MCSA to the political parties which condemned the apartheid system provides evidence of the Church's historical participation in politics. At the core of the establishment of the African National Congress (ANC) in 1912 was the involvement of the Church and her leaders. The ANC was influenced by faith and church people who had a conviction that the core of the struggle was the idea of inclusion of all people, moral progress, common citizenship and a non-racial society and nation. At that time, the leadership of the ANC that was influenced by Christian values was committed to social justice. This is against the background that the ANC had its first meeting in a Methodist Church building in Bloemfontein. The point that both Methodist ministers and laypersons historically led and openly participated in party politics, particularly in the ANC, is indisputable. These persons include Rev Dr E. J. Mqoboli, who was appointed as chaplain of the ANC; Rev Zaccheus Richard Mahabane, who led the ANC as its president from 1924 to 1927 and 1937 to 1940 . Rev Mahabane was an ordained minister of the MCSA. In 1940-1949, Sefako Makgatho, a lay leader and preacher, was elected as the president of the ANC. Dr J. S. Moroka, a lay person, who was the superintendent of the Methodist hospital at ThabaNchu in 1985, became a president of the ANC after President Xuma (MCSA 1958:69). Other Methodist ministers became presidents of other liberation political parties. Rev Dr S. Mogoba was elected president of the Pan African Congress in December 1997 after being the longest serving Methodist minister as executive secretary, and then as president and presiding bishop of the Methodist Conference. It is clear, therefore, that the MCSA clergy and laity have historically been active in party politics and, more importantly, they have offered valuable contributions to party politics. In addition, some of the Methodist clergy ministered to political parties while in full connection, while others made a conscious decision and resigned from the ministry of the MCSA. The case of Mvume Dandala who served as the president of the Congress of the People (COPE) is an example.

With respect to chaplaincy specifically in the ANC, the Methodist clergy historically provided a three-dimensional ministry (Mehana 2017). Firstly, the clergy person(s) provided spiritual direction and ministry. In this case, prayers for the members of the ANC were offered. In addition, the ANC became the recipient of the Word of God from the chaplain. Secondly, the clergy persons provided pastoral care. The members of the ANC who were in hospitals were visited and prayed for. Also, the members who were left in the country 
when their loved ones were in exile were offered counselling. Thirdly, the members of the ANC were provided education on morality. The chaplain offered teachings on 'revolutionary morality'. It may thus be deduced that in the capacity of being chaplain the Methodist clergy historically offered a positive contribution to party politics. This observation does not rule out the possibility of a negative contribution. Nonetheless, what can we say of the continued participation in party politics? Is there any theological rationale for the involvement of Christians and their leaders in party politics today?

\section{Chaplaincy in a Methodist Church of Southern Africa perspective}

The understanding of who and what is the chaplain is presented in The Methodist Book of Order. We thus draw on the understanding of chaplaincy, particularly in the context of Security Service, that is, in the army and the police services. The MCSA perspective on chaplaincy as embedded in The Methodist Book of Order is mainly about chaplains who minister in the context of Security Service rather than chaplains who serve within the political parties. The difference between chaplaincy to the Security Service and chaplaincy to political parties lies in the context, rather than in the ministry provided, and is supposed to be offered by an individual minister. In the present section, the focus is on the perspective of the MCSA on chaplaincy to the Security Service. However, we wonder whether such a perspective could be sustained in the context of political parties.

A chaplain is a minister who obtains the permission of the Quarterly Meeting and the bishop to render chaplaincy services (MCSA 2014:100). This is partly because of the fact that any minister in the connection is accountable to and is under the discipline of the Church. Not only does the MCSA deem chaplains as the 'representatives of the MCSA and must not conduct themselves in any way which will bring discredit on the good name of the Church', but it also sees chaplains as clergy persons who 'must remain faithful to the Methodist doctrines and values, especially in matters of conscience, and are encouraged not to bear arms' (MCSA 2014:162). We may thus wonder whether a chaplain in the political parties would not discredit the good name of the Church. It is impossible to separate the 'representativeness' of the MCSA from any minister, whether in the context of chaplaincy in Security Services or in the context of chaplaincy in the political parties. It is thus possible that a chaplain in the political sphere could discredit the good name of the Church.

Furthermore, a critical question to pose is the following: would a chaplain in the political parties remain faithful to the Methodist doctrines and values, especially in matters of conscience? Perhaps, if there are careful guidelines, the preceding concern would be addressed. However, it is also possible that based on the present MCSA understanding of who a chaplain is, a minister who is a chaplain in the context of party politics would find it difficult to 'remain faithful to the Methodist doctrines and values, especially in matters of conscience' (MCSA 2014:162). That difficulty may be because of the view that (MCSA 2014):

Chaplains are in a unique position as employees of the State. They are employed by, and are in a contractual relationship with the Security Service and are therefore responsible in the first instance to the authority and discipline of the Security Service concerned. (p. 162)

What this means is as follows: a chaplain is expected to uphold the values of a structure in the Security Service as in this case a chaplain is 'responsible in the first instance to the authority and discipline of the Security Service concerned' (MCSA 2014:162). In the context of party politics, especially based on the understanding of chaplaincy as reflected in the policy of the MCSA, a chaplain of a political party would be viewed as one who is responsible in the first instance to the authority and discipline of the political party concerned. In a case where the discipline of the political party is in contrast to that of the MCSA, the minister would be in a compromised position as he or she is equally expected to be guided by the discipline of the MCSA. It is necessary to note that although the chaplains may be in a contractual relationship with the structure outside the Church (MCSA 2014):

they continue to be in a covenantal relationship with the MCSA through their ordination and are also subject to the discipline and regulations of the MCSA in order to remain in good standing with the Church. (p. 162)

It must be emphasised however that the relationship of a minister with the Church takes priority.

The MCSA believes that a chaplain is a Methodist minister who is 'required to serve people of all denominations and faiths as well as members of the MCSA' (MCSA 2014:162). Meeting this requirement is possible in the context of the Security Service because in such a setting one finds employees from various backgrounds. Importantly, it is highly unlikely for a Methodist minister to serve all people in the context of party politics. It is also unlikely for a chaplain in a particular political party to serve 'all people', even those who are members of other political parties. However, if there are various chaplains rendering services to various political parties, respectively, it is possible to have a scenario where the Church as a collective may serve 'all people'.

The point that chaplains are required to report to the Synod is worthy of note. This point is important because it suggests that a chaplain in the MCSA is a minister who is accountable to the Church. In this instance, a chaplain shares his or her work with the Church. The church is subsequently in a position to critique and/or affirm the work of the chaplain outside the Church. In the context of party politics, such accountability would be possible, but only if the chaplain of a political party provides an annual report to the Synod. Although there might (not definitely so) be room for 
chaplaincy in political parties, it is necessary to establish whether there is a convincing argument for the participation of Christians, and most importantly the clergy, in party politics.

\section{The theological rationale for Christian involvement in party politics}

Interestingly, the argument that Christians in general may be active in 'politics' is less problematic as compared to the one that they may participate in 'party politics' (Tshaka \& Senokoane 2016:1). In other words, it is easier to accept the participation of Christians in general 'politics' than to accept their involvement in 'party politics'. This is because politics in the context of party politics is a contested space, especially in democratic countries. However, if political parties are constituted by human beings who are made in the Image of God, it makes sense to argue that the expression of Christianity and the ministry of the Body of Christ - the Church - should extend to all aspects of life, including the political sphere. Thus, it is reasonable to argue that 'to lead a spiritual life is to live as the people of God in all aspects of life' (Tshaka \& Senokoane 2016:1). A case in point is that the lordship of Christ that 'extends to all of life, including the political, social and economic areas of our existence', holds water (MCSA 2014:224).

Political governance 'implies deliberations, aspiration for rationality, and subjecting governance by folkways to questioning and criticism' (Hulled 1993:13). If this is the case, it is then reasonable for Christians to be part of the preceding process of deliberation. In an instance where the 'decisions about the economy, society and beliefs', among other issues, are made in the political sphere, especially within the political parties, it makes sense for Christians to be involved in such a process of decision-making (Tshaka \& Senokoane 2016:3). Importantly, the fact that many of the members of the MCSA are affiliated to political parties suggests that the Church is already involved in party politics.

The MCSA does not refute the participation of Christians in party politics. The theological reason for the MCSA not to condemn the participation of her members in party politics lies in the theology of 'free-will'. Undoubtedly, God created human beings with freedom of choice. Thus, it may be said that Methodist people may choose to affiliate to any political party and subsequently support any political ideals. However, as Methodism insists, it is imperative that the concept of 'free-will' should be coupled with the idea of Christian responsibility and obligation. Importantly, the juxtaposition of the concept of 'free-will' and the idea of 'freedom of choice' insists that 'each person's freedom to choose' should not be 'disadvantaged by someone else exercising their freedom' (Williams 2007:1). That is, one's freedom of choice should not infringe the freedom of other people. Thus, the participation of Christians in party politics should be guided by the biblical principles which urge Christians to live according to the will of God.
The contribution of Christians to party politics is not only spiritual but also moral. Christians are best fit to offer a positive contribution towards the moral behaviour of a political party. As stated by Tshaka and Senokoane (2016):

Christians cannot stand aloof, believing that politics is a dirty game, and complain about moral deterioration but failing to point the way for others in the leadership of political parties. (p.3)

It becomes clear that 'politics cannot be separated from ethical considerations' (Tshaka \& Senokoane 2016:2). As such, Sexwale's (1995) remark comes to mind:

Please - you must squat in our offices if we are not providing shelter to people ... The church must keep as close to us as saliva on the tongue. If you forsake us, if you abandon us - we will sin; we are just human. (p. 11)

The latter remark implies that politicians are not immune from the sinful nature of human beings. The possible immorality of the politicians necessitates a ministry on the part of the Church to call them to repentance and a sense of striving for perfection, as John Wesley would say. In addition, as Karl Barth (1939:150) argued, 'the Civil community as such is spiritually blind and ignorant' and it has neither faith nor love nor hope. Since the 'Civil community' includes both the state and political parties, it therefore becomes critical that Christians occupy the political space, and more importantly the sphere of party politics, to offer wisdom and guidance on issues of moral behaviour that is informed by their relationship with Christ. Because it is possible that Christians could offer harm to the 'Civil community' as they are also sinful human beings, the contribution provided by Christians needs to be within the framework of the doctrine and policy of the church. The contribution of the Church to party politics should thus reflect both a degree of faithfulness to its head, who is Christ, and dependence on the Holy Spirit for guidance.

It is worthy to note that some of the South African theologians, namely Senokoane and Kritzinger (2007), warned against the privatisation of Christianity by arguing that:

If we as Christians, who make up a statistical majority of $70 \%$ of South African society, do not commit ourselves to significant processes of people-centred development, anti-racism and church-re-unification, but continue in our lukewarm and comfortable private Christianities, we should not be surprised when South African society at large leaves us behind or even splits us out. (p. 1713)

In other words, choosing not to actively participate in the political activities of the community may lead to social isolation and a failure on the part of Christians to witness the Gospel of Christ. It becomes important that the church community creates room for the gospel in the world (Bonhoeffer 1995:355). The warning against the privatisation of Christianity is relevant in the discussion of party politics in the context of the MCSA. 
It is argued that (Tshaka \& Senokoane 2016):

the object of the promise and the hope in which the Christian community has its eternal goal consists of (according to the unmistakable assertion of the New Testament) not an eternal Church but the polis (community) built by God and that has come down from heaven to earth. (p. 5; cf. Barth 1939:154)

This observation is based on Revelations 21:2; 24: 'the nations shall walk in the light of his glory' and Matthew 25:31ff.: 'in the basileia [reign] of God - in the Judgment of the King on the throne of his glory'. Tshaka and Senokoane (2016) state:

Deducing from the teachings of the gospels as well as from the Letter to the Romans, Christians are called to offer 'supplications, prayers, intercessions and thanksgivings' for all of humanity and, in particular, for kings and all those in positions of authority. (p. 4)

\section{Thus:}

it is imperative to note that the church does not do these duties chiefly because it can come into good term with the state, but because it is called for to perform so. (p. 4)

The calling of the Church to extend the lordship of Christ in the political sphere therefore becomes the fundamental rationale for the involvement of Christians in party politics. A critical question to ask is: should the involvement of Christians in party politics be limited to members of the Church or should it include the Methodist clergy?

\section{Methodist ecclesiology on the 'duties of ministers' and its implications}

The bearing that the duties of Methodist ministers have on the debate on 'party political chaplaincy' needs to be investigated. The duties as stipulated by the MCSA (2014) include:

4.76. Ministers, as those who have been overwhelmed by the saving love of Jesus Christ, are called to proclaim by word and by deed this saving love for all people. As the Lord has accepted all sinners without condition, so ministers must declare unconditional acceptance and forgiveness for all. A Minister's duty is to use the pulpit to preach this Gospel and this Gospel only, preaching both pastorally and prophetically. Therefore they must faithfully nurture their own spiritual life, they must be diligent in preparation and in studying the Scriptures and other material which will provide equipment for their Calling, and their homes must be led in such a way as to be a witness to the Gospel. Ministers are to be servants of all Christ's people by being pastors to them in their homes and in every other situation. The Minister's duty is to set before the people by precept and example the ideal of Scriptural Holiness, and to instruct people in Christian faith and life.

4.77. Ministers are to preach and to perform all acts of Worship, to exercise oversight and to apply the Methodist Discipline, in the churches or other places of worship already erected or to be erected in the circuit to which they are appointed.

4.78. Ministers shall administer the Sacraments but shall not, without the approval of the Bishop, use set forms of worship for the Sacraments other than those that have been authorised by Conference.

4.79. Ministers shall observe and implement the provisions of Laws and Discipline and all other policies, decisions, practices and usages of the Church.

4.80. Ministers shall use every effort to maintain Class Meetings, directing both public instruction and private pastoral influence toward this object. (p. 41)

The fact that 'a Minister's duty is to use the pulpit to preach this Gospel and this Gospel only, preaching both pastorally and prophetically', highlights the critical use of the pulpit in ministry (MCSA 2014:41). A Methodist minister is therefore an interlocutor of the Gospel of Christ. Based on the Methodist theology and polity, the fact that the Gospel is partly meant to be conveyed in the pulpit emphasises the pivotal role of preaching in ministry. A Methodist minister is thus a person who appropriates scripture in a manner that is both pastoral and prophetic. What this means is that the bridge between scripture and society is established by a minister from the pulpit. As some of the Methodists are members of various political parties, the pulpit becomes a space where a clergy person may primarily minister to both members and leaders of political parties. In this space, the clergy person assumes a pastoral and prophetic role in a way that allows the Church to equally minister to political parties. However, the argument that the usage of the pulpit as a sole way to convey the Gospel of Christ is inconclusive mainly because the great commission directs the Church to go the world to 'make disciples of all nations, baptizing them in the name of the Father and of the Son and of the Holy Spirit' (Mt 28:19). As such, the Gospel may be extended to the people outside the pulpit and more importantly in other spheres of life where people are socially, economically and politically located.

The view that 'Ministers, as those who have been overwhelmed by the saving love of Jesus Christ, are called to proclaim by word and by deed this saving love for all people' is critical in understanding the ministry of a clergy person in the life of the Church and community (MCSA 2014:41). Because the proclamation of the saving love of Jesus Christ needs to be made to all people, the MCSA's belief that the lordship of Christ extends to all of life, including the political, social and economic areas of our existence' is compelling (MCSA 2014:224). The Methodist clergy person is thus one who avails the lordship of Christ to all people. In this case, not only does the Methodist theology provide a reason for the involvement of the clergy in the political sphere, it also calls for ministry in the political spheres. The point that the phrase 'all people' is inclusive is in contrast to a selective and exclusive model of ministry is decisive. In the context of party politics, the implication of Methodist ecclesiology is as follows: the lordship of Christ needs to be availed to many political parties rather than to a single party. In other words, a situation where the Church, through her clergy persons, ministers to a single political party stands in discontinuity with the 
Methodist ecclesiology. Methodist theology on the church also insists that ministry should be extended to governments, national parliaments, provincial, regional and municipal institutions and traditional spheres of leadership.

The view that 'Ministers are to be servants of all Christ's people by being pastors to them in their homes and in every other situation' supports the call for ministry in the political sphere (MCSA 2014:42). However, the preceding view also poses a problem. As mentioned before, it is also unlikely for a chaplain in a particular political party to serve 'all people', even those who are members of other political parties. Nonetheless, given the point that political parties influence the lives and moral compass of the Methodist congregants, particularly in the political sphere and, most importantly, based on the Methodist ecclesiology, it is therefore imperative that the Church, through her clergy, occupies the political space. As the MCSA puts it, 'in the Providence of God Methodism was raised up to spread Scriptural Holiness throughout the land by the proclamation of the Evangelical Faith' (MCSA 2014:11). A critical dimension to Methodism is the spread of holiness in many spheres of life. The idea of spreading Scriptural Holiness brings to mind Benefiel's (2006) argument:

It is the character of the people of God to engage the world in mission in a similar way that God has displayed in Christ Jesus, that is to say, incarnationally. Rather than moving away from the sin, pain and suffering of the world, the character of holiness in the people of God inclines them to move right into the midst of such a world. (p. 137)

Based on the preceding remark, the MCSA clergy are called to exhibit the incarnational approach to ministry that was exemplified by Christ, the Lord of the Christian Church. If 'the original purpose of Methodism is "to spread scriptural holiness throughout the land"' as correctly suggested by the MCSA, the ministry of the clergy in various political parties may thus be viewed as being within the Methodist ecclesiology (MCSA 2014:172).

\section{Methodist ecclesiology on the clergy and party politics}

The Methodist theology on the Church, her people, and more importantly the clergy, as well as on her relationship with the political parties is embedded in The Methodist Book of Order. The MCSA (2014) believes that:

\begin{abstract}
A Minister who takes up a party-political post or any other appointment that Conference or the Connexional Executive considers as compromising the independence of the Church in its witness, shall resign from the Ministry, failing which they shall be deemed to have resigned. (p. 43)
\end{abstract}

The spirit behind this position is that all clergy persons in the MCSA are the custodians of the witness of not only the Church but also Jesus Christ. In the political sphere, the Methodist minister is one who may not compromise the prophetic voice of the Church. Related to the preceding position of the MCSA is the one on seconded ministers. The MCSA (2014) holds that:

Secondment shall only be granted if the position is considered to be in harmony with the ministry and mission of the Methodist Church of Southern Africa. It shall not be granted for positions of a party-political nature, or any appointment which compromises the necessary independence of the Church in its witness to the Gospel in society. (p. 44)

This means that any work of a minister outside the context of the MCSA should be in harmony with the ministry, vision and mission of the MCSA. It must however be noted that it is rather difficult to make a diagnosis of the discord between the work of the minister outside the church and ministry and mission of the MCSA because the mission of the Church is complex and dynamic. Based on the argument of the work being in harmony with the mission of the Church, and given the preceding point, there is thus no convincing ground to argue that the work of a minister in a political party is in discord with the vision and mission of the Church. However, the spirit of the following statement is decisive (MCSA 2014):

It shall not be granted for positions of a party-political nature, or any appointment which compromises the necessary independence of the Church in its witness to the Gospel in society. (p. 44)

For instance, in a case where the witness of the Gospel is 'integrity', the association of a Methodist minister with a group or political party or members of a political party who are found by a court of law or alleged to be 'corrupt' would therefore compromise the image of a 'righteous' and the witness of 'integrity'. Thus, it is critical that the Church establishes and maintains a careful space between the political parties and the Methodist ministers.

With regard to the MCSA position on the 'membership of political parties by ministers', worthy of note is the point that (MCSA 2014):

The Church has an obligation to act as mediator on behalf of God in society and therefore Ministers should seriously examine their conscience whether to be seen to be members of any political party. (p. 226)

Acting 'as mediator on behalf of God in society' suggests that in a case where any political party is doing harm to the society, the Church, and most importantly the ministers, should be critical of that party. In other words, the ministers (or MCSA structures) need to be in a position of pronouncing criticism to a political party. The district bishops as well as the presiding bishops are in a better position to criticise a political party that is doing harm to the society. A question to ask is whether individual ministers would be in a better and strategic position to criticise a political party from within the structures of such a political party, such as branch meetings, provincial gathering and national conferences. This would be possible if Methodist ministers are part of an independent structure that comprises other ministers or religious leaders from other churches and religious formations. In this case, 
one (a minister) would be protecting the independence of the church.

The point that 'Ministers should seriously examine their conscience whether to be seen to be members of any political party' is critical (MCSA 2014:226). Ministers of the MCSA, as leaders, carry an extra moral and ethical responsibility that calls for conscience, whether to be seen to be members of any political party. It must be admitted that the presence and participation of a minister in the activities of a certain political party, and not in the events of other political party, may easily be construed as 'membership to a political party'. In other words, although there might be no evidence of membership to a political party, through his or her participation in the gatherings of the political party, such as branch meetings, provincial meetings and national conferences, such a minister may be 'seen to be a member' of that political party. It is rather difficult, if not impossible, to control the perceptions that the society may formulate in this case.

Based on the present discussion on the 'Methodist ecclesiology on the clergy and party politics', it rather seems safe to argue that Methodist ministers should refrain from participating in the activities of political parties either by conducting opening prayers or through participation in the discussion of policies. However, we still wonder what the pastoral and prophetic nature of ministry is in the political and public space, as such ministry is fundamental.

\section{Pastoral and prophetic nature of ministry in the political and public space $^{1}$}

It is necessary to acknowledge that each Christian is created by God with a unique capacity and calling (Williams 2007:1-8). The fact that 'the recognition that every person is related to God before they are related to anything or anyone else' as well as the awareness that 'God has defined who they are and who they can be by his own eternal purpose' suggests that one's ministry in the public sphere is, in its nature, a response to God's calling (Williams 2007:2). An individual and the Church should thus discern such a calling. Christians therefore receive both the calling and the spiritual gifts to minister in the political and public sphere. Importantly, 'when human beings are brought into relationship with Jesus Christ by faith as a community in which everyone's gifts are set free for the service of others', the Church may in turn create space for each person to offer their gifts, and more significantly their ministry to other people in all spheres of the community (Williams 2007:5). It may therefore be noted that (Williams 2007):

the stress in Christian thinking on the active responsibility laid on each person means that whether government or private initiative takes the lead, there is a calling to be involved in the work of setting each other free to respond to the possibilities opened up by God. (p. 5)

1.This section is partly based on the lecture given by Rowan Williams (2007), the then archbishop of Canterbury at St Andrew's Cathedral in Singapore.
Concerning the Church's relationship with political power, a caution on compromising the necessary independence of the Church in its witness to the Gospel should be made. In certain instances, when churches have directly tried to exercise political power, they have often compromised their real character as well as their independence in its witness to the Gospel of Christ. As mentioned earlier, literature on the church's relationship with the apartheid government reveals the way the Church compromised her independence in its witness to the Gospel. However, when the churches have retreated in the face of power, as is the case in the postapartheid South Africa, it may be argued that 'they have risked betraying (betrayed) their distinctiveness' as well as their calling to extend the lordship of Christ to all people in all spheres of life (Williams 2007:5). Williams (2007) also states:

Christians are called; it seems, to live out the vision of relationships in the Body of Christ without fear of conflict with the rest of society; because sometimes that living out of these relationships can be unpopular with society. (p. 6)

In other words, the prophetic nature of the calling and role of the Church may render her unpopular. However, God calls the Church to minister without fear of conflict with the society. Inasmuch as the Church may affirm the good works of the political parties as well as political structure, she is also called to be critical of them, especially when the behaviour of politicians is harmful to the society. However, the Church is 'not called to impose' her 'vision on the whole of society', including the political parties (Williams 2007:6).

In the context of governance, be it in national parliaments, provincial, regional and municipal institutions and traditional spheres of leadership, Christians may assume the role of arguing 'that the voice of faith should be heard clearly in the decision-making processes of society' (Williams 2007:6). What this means is that the ministry of the Church transcends the provision of spiritual disciplines such as prayer and spiritual direction, among others. The Church is also called to extend the lordship of Christ to processes that impact many people in the society. As Williams (2007) pointed out:

... the churches do not campaign for political control (which would undermine their appeal to the value of personal freedom) but for public visibility - for the capacity to argue for and defend their vision in the public sphere, to try and persuade both government and individuals of the possibility of a more morally serious way of ordering public life. (p. 7)

In addition (Williams 2007):

A healthy democracy, then, is one in which the state listens to the voices of moral vision that spring from communities that do not depend on the state itself for their integrity and meaning - above all the communities of faith. (p. 7)

It is noteworthy that the Church is and may be a conversational partner with the political parties and structures of governance where she calls for moral priorities. Being a conversational partner suggests that the Church extends a call 'for a proper 
hearing of its concerns and - ideally - willingness on the part of political leaders to show self-critical honesty and, where appropriate, repentance' (Williams 2007:8). It is not that the political parties and governance structure as well as the laws of society 'must represent in all respects the commands of the gospel'; it is rather that the political parties and governance structure are 'continually engaged in conversation with those who speak for the Gospel' (Williams 2007:8). In this case, the Church becomes a critical friend to the political parties and/ or governance structure as well as its laws.

Regarding the Church's relationship with national parliaments, provincial, regional and municipal institutions, Forster (2012:73-88) and Bentley (2014:1-8) have already cautioned us. For Bentley (2014:2), 'the South African Constitution makes provision for freedom of religion', and 'freedom of association' as well as 'freedom of expression for all' (cf. Republic of South Africa 1996:5, 16, 18). Although these three rights provide the platform for the place of religion in the new South Africa, they have however led Christianity to surrender a place of privilege (Bentley 2014:2). In other words (Bentley 2014):

the adoption of the South African Constitution meant that the voices of different religions now carry equal weight. Christianity is now on par with other religions, or shall we rather say that all religions are on equal footing. (p. 2)

Interestingly, Forster (2012:73-88) affirms Prozesky's (2009) explanation of the concept of 'secular state', which can be summarised as follows:

1. The secular State affords freedom of religion to all whom it governs. In a religious State, faith is enforced and may be in conflict with the convictions and beliefs of some or many of its citizens. From the Christian perspective, faith is a matter of conviction and cannot be imposed.

2. In a religious State, the relationship between religion and State is blurred and it would be difficult for religion to speak prophetically when needed. The secular State is far enough removed from religion for religions such as Christianity to engage those in power.

3. Christians are not only concerned about their own rights, but also the rights of those who belong to other faith groups and vice versa. The secular State affords the opportunity for religions to speak for each other, whereas in a religious State, one religion would have an elevated place above another.

4. In a secular State, all religions enjoy equality before the law and have similar rights. Any politico-ideological alliance between a religion and the State would create an imbalance in this context and becomes the breeding ground for religious intolerance and discrimination. (pp. 244-253)

The preceding summary suggests that the ministry of the Church to government structures, such as national parliaments, provincial, regional and municipal institutions, should be within the framework of a religious community. This means that the Church's engagement with the state and/or state structure should be through a national, provincial, regional and municipal leadership structure of the religious community. As South Africa is a secular state guided by the constitutional democracy, an interaction of an individual minister with government structure is questionable. The idea of a 'secular state' also suggests that the presiding bishop may only formally engage and interact with the government structures within the context of leadership structure of the religious community.

\section{Towards a position on ministry to political parties}

Based on the discussion above, we may thus attempt to navigate the possible position on ministry to political parties that the MCSA may consider. Thus, it is imperative to set some options that we may ponder. These include:

\section{Option 1}

- Only the circuit superintendents, district bishops and the presiding bishops shall provide ministry to the political parties. That ministry may be in the form of prayer and leading devotions at the event of any political party. Also, the ministry may be in a form of providing education on issues of ethics and morality as well as of political economy.

- At a local level, that is, branch level, the circuit superintendent may provide ministry to a political party.

- The district bishops may minister to political parties at a provincial level when invited.

- At a national level, only the presiding bishop shall provide ministry to all political parties.

- The pronouncement of a prophetic voice to any political parties that seem to be doing harm to the society shall exclusively be made by the presiding bishop.

\section{Option 2}

- Any minister may provide ministry to any political party, only after having been granted permission by a circuit superintendent, district bishop or the presiding bishop.

- A minister who is granted permission should provide a written report to the circuit Superintendent or District Bishop or the Presiding Bishop on the ministry offered to political parties.

- Permission to minister to political parties or political structures will only be granted where the minister concerned is competent and acceptable and considered a worthy representative of the Church.

- A minister desiring to accept an invitation from a political party to provide ministry shall instruct the political party in question to submit a written request with appropriate motivation to a circuit Superintendent, District Bishop or the Presiding Bishop.

- At a local level, the circuit Superintendent may grant permission for a minister to provide ministry to a political party. 
- The District Bishops may permit the minister to provide ministry to political parties at a provincial level.

- At a national level, only the Presiding Bishop shall grant permission for a minister to provide ministerial services to all political parties.

\section{Option 3}

- In a case where a minister is not a member of a political party but feels a call to minister to a political party, he or she shall resign from the ministry of the Methodist Church of Southern Africa.

A critical question to pose is as follows: which option(s) could constitute a reasonable and convincing position for the MCSA? A cogent argument on the possible ministry of Methodist clergy persons to political parties in South Africa ought to be grounded on the discourse of the history of the MCSA in the political sphere and the MCSA perspective of chaplaincy. In addition, the theological rationale for Christian involvement in party politics as well as the Methodist ecclesiology on the duties of ministers in the context of party politics directs a need for the formulation of a position on the pastoral and prophetic nature of ministry in the political and public space.

On a historical level, it is undeniable that the MCSA had directly and indirectly been involved in politics. As mentioned earlier, prior to 1994 democratic elections in South Africa, the MCSA criticised the apartheid system that was oppressive to the majority of the South African people. On this point, the involvement of the MCSA members is commendable. However, concerning the ethical and moral evaluation of the MCSA's involvement with the liberation movement, it may be argued that some of the MCSA members partook in terrorist acts where civilians including women and children were victims. It is rather difficult to sustain the preceding possible argument, as there is no evidence to support such a speculation and likely allegations. Thus, we submit that the positive contribution of the MCSA in the political sphere in the history of South Africa gives no reason to reject possible ministry in the present political sphere. From an ethical and moral point of view, the involvement of the members of the MCSA in the political sphere which does not do harm to humanity may be validated. Based on this view, options 1 and 2 are convincing.

Based on the MCSA perspective on chaplaincy, it is cardinal that we navigate a position on the ministry to political parties. Because the lordship of Christ 'extends to all of life, including the political, social and economic areas of our existence', it is reasonable that any minister may provide ministry to any political party (cf. MCSA 2014:224). However, grounded on the point that a Methodist minister is a 'representative' of the MCSA and should not discredit the good name of the Church, a position that warrants accountability is conclusive. Undoubtedly, clergy persons who minister to political parties must also 'remain faithful to the Methodist doctrines and values, especially in matters of conscience, and are encouraged not to bear arms' (cf. MCSA 2014:162). Drawing on the MCSA perspective on chaplaincy to Security Service, it is reasonable to argue that based on the aforementioned perspective, though in a different context, any clergy person in the MCSA may provide ministry to political parties as chaplains. On this point, option 2 makes sense.

The bearing that the duties of Methodist ministers have on the debate on 'party political chaplaincy' points at the direction that any minister may provide ministry to any political party, only after having been granted permission by a circuit superintendent, district bishop or the presiding bishop. The point that the MCSA clergy are called to exhibit the incarnational approach to ministry that was exemplified by Christ, the Lord of the Christian Church, validates ministry to political parties. This also means that ministers may open rallies and other political meetings in their church uniforms and may participate in protest action and other public events in their church gowns. Undoubtedly, the participation of ministers in party political events while in official church clothes enhances the visibility of the Church in the political sphere. The MCSA position that the ministry of the Church extends to all spheres of life further supports the preceding view.

The does not seem to be a compelling reason for option 3 which stipulates that in a case where a minister is not a member of a political party but feels a call to minister to a political party, he or she shall resign from the ministry of the MCSA. This holds true because based on the discussion above any minister may provide ministry to political parties. It is only in an instance where a minister seeks to be a member of a political party that he or she may be compelled to resign from the ministry of the MCSA. Furthermore, option 1 seems to be inconclusive because all ministers are called to serve humanity in all spheres of life. This call is not restricted to circuit superintendents, district bishops and the presiding bishops. However, it is important that all ministers account to the Church. That any minister should be granted permission and report to the circuit superintendent or district bishop or the presiding bishop provides for the level of accountability to the Church. It is therefore our view that option 2 is reasonable.

\section{Conclusion}

Based on the literature of the MCSA (The Book of Order) as well as on the theological scholarship in and outside the MCSA, this article mainly argues that any minister may provide ministry to any political party as a chaplain. The discussion on the history of the MCSA in the political sphere and the MCSA's perception on chaplaincy as well as the debate on the theological rationale for Christian involvement in party politics validates the main argument of the present essay. Furthermore, the discourse on the Methodist ecclesiology on the 'duties of ministers' as well as on the clergy and party politics does not provide a compelling 
reason for Methodist ministers to distance themselves from participation in the political sphere. In addition, the pastoral and prophetic nature of ministry in the political and public space is affirmative to the argument that any clergy person in the MCSA may provide ministry to political parties. Importantly, suffice to say, the debate about chaplaincy to political parties is far from being exhausted in the MCSA and the South African ecclesiastical circles. Thus, this article offers some contribution to the continuing pertinent discourse on the involvement of churches in the South African political sphere.

\section{Acknowledgements Competing interests}

The authors declare that they have no financial or personal relationships that may have inappropriately influenced them in writing this article.

\section{Authors' contributions}

N.M. and S.S.M. equally contributed to the research and writing of this article.

\section{References}

Barth, K., 1939, Church and state, Student Christian Movement Press, London.

Benefiel, R., 2006, 'Christian holiness and the Wesleyan mission of mercy: The character of the people of God in the World', in J.S. Park (ed.), Holiness as a root of morality: Essays on Wesleyan ethics: Essays in honor of lane A. Scott, pp. 125-150, Edwin Mellen Press, Wales.
Bentley, W., 2014, 'Methodism and transformation in South Africa: 20 years of constitutional democracy', HTS Teologiese Studies/Theological Studies 70(1), 1-8. https://doi.org/10.4102/hts.v70i1.2673

Bonhoeffer, D., 1995, Ethics, Fortress Press, Minneapolis, MN.

De Gruchy, J.W., 1986, The Church struggle in South Africa, 2nd edn., David Phillip, Claremont, CA.

Forster, D.A., 2012, 'God's kingdom and the transformation of Society', in W. Bentley \& D.A. Forster (eds.), Between capital and cathedral: Essays on churchstate relationships, pp. 73-88, Research Institute for Theology and Religion, Pretoria.

Hulled, L.S., 1993, Christianity and modern politics, Walter de Gruyter, Berlin.

Mehana, V., 2017, Interview on political chaplaincy, Pretoria.

Methodist Church of Southern Africa (MCSA), 1958, Minutes of the seventy-fifth annual conference of the Methodist Church of South Africa, Methodist Publishing House and Book Depot, Cape Town.

Methodist Church of Southern Africa (MCSA), 1982, Minutes of Conference of the Methodist Church of Southern Africa, Methodist Publishing House, Cape Town.

Methodist Church of Southern Africa (MCSA), 2014, The Methodist book of order: The laws and discipline of the Methodist Church of Southern Africa, Methodist Publishing House, Cape Town.

Prozesky, M., 2009, 'Is the secular state the root of our moral problems in South Africa?', Alternation 3, 237-253.

Senokoane, B. \& Kritzinger, J.N.J., 2007, 'Tambach remixed: “Christians in South African society"', HTS Teologiese Studies/Theological Studies 63(4), 1691-1716. https://doi.org/10.4102/hts.v63i4.256

Sexwale, T., 1995, 'Church and state', in South African Council of Churches (eds.) Being church in a new land: A selection of papers presented at the 1995 National Conference of the South African Council of churches, pp. 9-15, Edenvale Printers, Johannesburg.

Republic of South Africa, 1996, Constitution of the Republic of South Africa, 1996, Government Printer, Pretoria.

Tshaka, R. \& Senokoane, B., 2016, 'The Christian politician? An investigation into the theological grounding for Christians' participation in politics', HTS Teologiese Studies/Theological Studies 72(1), 1-7. https://doi.org/10.4102/ heologiese Studie

Villa-Vicencio, C., 1986, Between Christ and Caesar: Classic and contemporary texts on Church and State, David Philip, Cape Town.

Williams, R., 2007, 'Christianity: Public religion and the common good', Paper read at the St Andrew's Cathedral in Singapore, 12 May 2007, viewed n.d., from http:// www.archbishopofcanterbury.org/495 